This is a self-archived - parallel published version of this article in the publication archive of the University of Vaasa. It might differ from the original.

\title{
Caste-Based Discrimination, Microfinance Credit Scores, and Microfinance Loan Approvals Among Females in India
}

Author(s): Patel, Pankaj C.; Lenka, Sambit; Parida, Vinit

Title: $\quad$ Caste-Based Discrimination, Microfinance Credit Scores, and Microfinance Loan Approvals Among Females in India

Year: $\quad 2022$

Version: Accepted manuscript

Copyright (C)2022 Sage Publications. The article is protected by copyright and reuse is restricted to non-commercial and no derivative uses. Users may also download and save a local copy of an article accessed in an institutional repository for the user's personal reference.

Please cite the original version:

Patel, P. C., Lenka, S. \& Parida, V. (2022). Caste-Based Discrimination, Microfinance Credit Scores, and Microfinance Loan Approvals Among Females in India. Business and Society 61(2), 372-388.

https://doi.org/10.1177/0007650320982609 


\title{
Caste-based discrimination, microfinance credit score, and microfinance loan approvals among females in India
}

\begin{abstract}
We draw on the phenomenon of caste-based discrimination in India and signaling theory to assess whether microfinance credit scores improve the odds of female micropreneurs from a lower caste receiving loans and whether visible business characteristics further improve the odds of receiving microfinance loans. In a sample of 3,144 female microfinance loan applicants at a female-focused microloan enterprise in India, females from a lower caste, relative to those from a higher caste, have lower odds of receiving loans when their credit scores are below the mean. However, when females from a lower caste have credit scores higher than the mean, the odds of receiving a loan increase. The practical effect of size is small but meaningful. Loan applicants from a lower caste with a visible signal of business ability do not improve their chances of receiving a loan relative to those from a higher caste.
\end{abstract}

Keywords: microfinance, caste, credit score, adverse selection

In 2016, microfinance institutions had 123 million customers with $\$ 102$ billion in loans (Microfinance Barometer, 2016). With women from rural areas constituting a majority of microfinance borrowers, microfinancing has increasingly become a tool for the economic and social well-being of millions of women around the world. Yet, gender-based discrimination has been widely documented in microfinancing markets (Agier \& Szafarz, 2013). One mechanism to 
reduce this bias is to rely on microfinance credit scores (Serrano-Cinca et al., 2016). A credit score is a mode of statistical discrimination or profiling (National Research Council, 2004).

Though credit scores in microfinance are a welcome change, deeply rooted social biases against females from certain groups in society could limit their efficacy. Caste-based discrimination and an institutionalized discrimination framework, rooted in ancient, social, and religious institutions (Deshpande \& Sharma, 2013; Jodhka, 2016), may lower the efficacy of credit scores in microfinancing. Whether the credit score as a financial solution can lower the negative effects of institutionalized discrimination is an important research question for both academics and microfinance institutions, especially in the case of India, a leader in microfinance (Microfinance Barometer, 2016). Additionally, a variety of studies in financial lending have highlighted the value of business ability as a signal in overcoming labor market frictions (Campbel \& Kracaw, 1980). Signals may help overcome the twofold impediment - being a female and coming from a lower caste - in lowering information asymmetry. However, the potential of visible signals of business ability to overcome institutionalized discrimination may be questioned because loan officers may not rely solely on credit scores to make caste-blind decisions and because caste-based discrimination may persist, lowering the fidelity of such signals to loan officers.

We draw on caste-based discrimination (Iyer et al., 2013) and signaling theory (Stiglitz, 1990) in posing two research questions: (i) Are female micropreneurs from a lower caste at a disadvantage relative to females from a higher caste in receiving microfinance loans? and (ii) If females from a lower caste are indeed at a disadvantage relative to females from a higher caste, can a signal of business ability improve their odds of receiving microfinance loans? Using a unique data set of 3,144 female microfinance loan applicants at a female-focused microloan enterprise in India, we find that caste-based discrimination declines with scores above the mean - possibly 
indicating a transition from taste-based discrimination to statistical discrimination. However, additional signals of business ability do not necessarily improve the odds of receiving loans for females from a lower caste relative to females from a higher caste. Our findings demonstrate limited efficacy of credit scores below the mean, and the lower complementary value of the business ability signal, support findings on the persistence of inequality, highlighted in the broader management literature in general (Bapuji et al., 2019), and sociological studies on caste and inequality in particular (Jodhka, 2016). Our findings also complement prior research on systemic hurdles faced by female entrepreneurs (Henry et al., 2016; Justo et al., 2015), delving further into heterogeneity among female entrepreneurs to augment understanding of an additional layer of discrimination - caste.

\section{Theoretical Development and Hypotheses}

Institutionalized discrimination is rooted in the social dominance theory where social hierarchy based on social, demographic, and religious dimensions results in the oppression of minorities (Sidanius \& Pratto, 2001). Examples of institutionalized discrimination include racial bias, the caste system, apartheid, and gentrification. Self-employment could be a dignified and desirable alternative to wage employment for lower caste individuals. Yet, entrepreneurs from a lower caste face significant constraints ranging from securing access to resources and capital to economic dependence on stakeholders from a higher caste (Thorat, 2010). Using the India Economic Census of 1990, 1998, and 2005, Iyer et al. (2013) found that scheduled caste (SC) and scheduled tribe (ST) members are less represented in business ownership and the percentage of the workforce employed by businesses. Self-employed from a lower caste (p. 38) earn less and perceive lower earnings as remunerative (Goel \& Deshpande, 2016) with "Scheduled Castes and Tribes (SCSTs) 
and non-SCSTs [self-employed had] as much as 55\% of the caste earnings gap" (Deshpande \& Sharma, 2016, p. 325). To overcome such caste-based discrimination, credit scores may offer a viable tool to reduce discrimination in lending to lower caste female micropreneurs.

\section{Caste, Credit Scores, and Female Micropreneurs}

Credit scores in microfinancing could lower caste-based discrimination and, thereby, reduce the borrowing disadvantage in microfinancing, especially for females who face added hardships in entrepreneurial pursuits in developing countries (De Vita et al., 2014). A credit score provides a uniform and objective criterion for all loan officers to follow. Rooted in the universalistic model of creditworthiness (Henderson, Herring, Horton, \& Thomas, 2015), microfinance credit scores aim to reduce the effects of demographic and social attributes in the making of credit decisions. A body of work has emerged on developing algorithms to determine microfinance credit scores (Bumacov et al., 2014; Gutiérrez-Nieto et al., 2016; Karlan \& Zinman, 2008). However, the creditscore generation process remains a human-intensive process (Van Gool, Verbeke, Sercu, \& Baesens, 2012) and, while may reduce lending frictions, it must be used judiciously given that the microfinance-based credit history of an applicant could be limited (Gutiérrez-Nieto et al., 2016).

However, the presence of a credit score may not be strong enough to counterbalance institutionalized discrimination rooted in socio-religious institutions. In loan decisions, the decision-makers may harbor implicit and explicit biases against lower-caste micropreneurs. With surnames often revealing caste, discrimination is further likely in a setting where females are already discriminated against in business undertakings (Deshpande \& Sharma, 2016; Jodhka, 2010). Explicit bias in terms of perceived roles and status can also cloud an officer's judgment in fairly assessing the prospects of an applicant. Applicants from the upper caste may be perceived 
as more trustworthy and reliable and, consequently, decisions may reflect a bias against lowercaste groups. Therefore, despite a comparable credit score, caste-based discrimination would disadvantage lower-caste female applicants. Further magnifying the effects of discrimination, microfinance loan officers may consider the under-representation of lower-caste individuals in the business sector and their smaller, less professionalized, and largely informal enterprises as a rationale for denying them loans despite comparable credit scores (Deshpande \& Sharma, 2013; Iyer et al., 2013). In proposing the following hypothesis, we expect that institutionalized discrimination forces will reduce the effectiveness of credit scores:

Hypothesis 1 (H1): Relative to a female applicant from a higher caste, the likelihood of receiving a loan is lower for a female applicant from a lower caste.

Signaling theory - Visible signals of business ability

While caste-based discrimination can bias loan approvals in favor of entrepreneurs from a higher caste, asymmetric information theory in loan markets suggests that the availability of additional signals of business ability should reduce such bias (Cornée, 2017). Our logic for overcoming castediscrimination challenges through business ability signaling is rooted in Parker's (2002) argument that: "some loan applicants are denied a loan altogether, despite (i) being willing to pay more than banks' quoted interest rates to obtain one, and (ii) being observationally indistinguishable from borrowers who do receive a loan" (p. 163). Micropreneurs from a lower caste with more visible signals of their business ability would imply lower transaction and monitoring costs and should, therefore, help to surmount prejudice and information asymmetry. In a qualitative survey of ninety Dalit businesses in six states in India, Prakash (2010) found that lower-caste business owners were obliged to borrow informal loans at a higher rate and that, in the formal loan markets, banks 
discriminate against lower-caste loan applicants (Kumar, 2013). In a sample of microfinance institutions from Mexico, Bauchet et al. (2018) found that the purchase of life insurance to accompany the microfinance loan was a costly signal that lowered the odds of default. These studies add some weight to the case for signaling in microfinance.

Business ability could be signaled by the size of the business and the years in selfemployment, among other indicators. Business size is especially salient given that size remains a critical constraint for small businesses (Aldrich \& Auster, 1986). Loan applicants who can signal larger business size - an observable costly signal - may be deemed to attract resources and employees and to have larger buffers against the financial vicissitudes faced by small businesses. A larger business size signals lower odds of failure (Baum \& Shipilov, 2006) and, therefore, higher odds of repaying microfinance loans. Providing an additional signal of business ability reinforces the credit score information and improves the odds of receiving a loan. Based on this logic, we propose the following hypothesis:

Hypothesis 2 (H2): With an increasing microfinance credit score, the likelihood of receiving a loan will increase for a female applicant from a lower caste, relative to a female applicant from a higher caste, when complemented with a signal of business ability.

\section{Methods}

Data and Sample

To examine these hypotheses, we draw on data from one of the leading microfinance companies in India. We refer to this company as Microloan Enterprise. With its primary focus on female micropreneurs, Microloan Enterprise is a pioneer in the microfinance field. It launched operations almost two decades ago and, by 2018, controlled an exceptionally large portfolio of over 800 
million USD and two million customers. Its operations are spread across the country in over eight states encompassing the south, the central region, and parts of eastern and western India. Due to its focus on recording and storing information digitally, we were able to gain access to data on its customers and its microfinance credit scores for a city in southwestern India. The operations in this city include eight branches located within and around the city. The evaluation process is very detailed with many more checks and balances than a group loan, encompassing both personal and business information that is commonly not found in the context of microfinance. The organization uses third-party credit scores and has clear policies, standardized guidelines, and uniform loanorigination processes to ensure that all loan applications are appraised fairly and effectively.

Following case-wise deletion, our final sample includes 3,144 first-time female loan applicants who have been Microloan Enterprise's group-loan customers for at least two years. The sample represents the entire universe of individual business loan applications that were received from female micropreneurs by Microfinance Enterprise in the city. The loan applicants were engaged in running micro-businesses such as Kirana stores (small, multi-purpose, retail stores), tailoring services, manufacturing and retailing food products, incense making, carpentry, weaving, mobile phone retailing, and scrap vending.

\section{Measures}

Our main outcome variable is whether an applicant has received a loan (1=yes; $0=$ no). The predictor variable is the microfinance credit score, which is provided by a third party - a specialized agency that provides credit scores based on an individual's microfinance-related behavior. This credit score captures the individual's previous credit-related behavior in servicing debt from a recognized microfinance institution. It does not take into account the individual's credit 
behavior in relation to products or services from other consumer financial institutions such as banks or non-banking financial institutions (NBFCs). This credit score is based primarily on three factors: (i) the number of previous loan applications that have been rejected by microfinance institutions; (ii) the number of scheduled loan repayments that have been delayed; and (iii) the number of defaults in loan repayments.

Given the limited differences between the general caste and other backward castes (Deshpande \& Sharma, 2016), in our test for Hypothesis 1, we code these two categories as zero and SC/ST categories as one. The moderator is SCST or non-SCST as the members of Other Backward Caste are closer economically and socially to the general caste category. Although theologically, caste does not apply to non-Hindu communities, some non-Hindus identify with certain caste structures due to complex socio-economic and historical factors (see the additional discussion in the controls and robustness test section).

To test for Hypothesis 2, we use the log of the business premises in square feet. The size of the business premises, though not ideal, is liable to reduce the misreporting of bias. Business square feet, controlling for business type, provides a visible signal of business ability and could help improve the odds of receiving loans in tandem with a higher microfinance credit score, despite being from a lower caste. Owning or renting real estate is a high fixed-cost expense, and square footage of the business, controlling for the type of sector (e.g., manufacturing, services, trade) is a readily verifiable metric of the degree to which the business has overcome the liability of smallness.

We include a variety of control variables. We include the loan amount requested. We also include age (in years), education (illiterate; less than $10^{\text {th }}$ grade; $10^{\text {th }}$ pass; $12^{\text {th }}$ pass; graduate; or post-graduate), marital status (married; separated; unmarried; or widowed), and religion 
(1=Christian; $2=$ Hindu; or 3=Muslim). Because microfinancing is based on local relationships, we include the years of residence in the current city as a proxy for residential stability. The sector of an individual's business (agriculture, manufacturing, other, services, and trading) is also included. Finally, we add the family type ( $0=$ joint; $1=$ =nuclear $)$.

-Insert Tables 1-2 and Figure 1 about here-

\section{Results}

In Figure A1 (Online Appendix), we present the quintiles of the credit-score distributions. The scores are somewhat uniformly distributed across caste categories. However, for the range of 571 to 758 , members of the ST category have rather lower scores. In the box-whiskers plot for the ST category, the interquartile range (the length of the box) is larger. Finally, we present the pie plots to demonstrate the distribution of credit scores across quintiles.

Table 1 presents the item descriptives. Table 2 presents the results based on odds ratios from the logit regression. We note that, though the odds ratios for credit scores are small, the interpretation is for a one-point increase in credit score. In Model 2, a higher credit score is positively associated with the odds of receiving a loan. Therefore, for a 10-point increase in credit score, the odds of receiving a loan are 1.04 times greater in Model 8.

Testing for Hypothesis 1, a higher microfinance credit score increases the odds of receiving a loan to a greater degree for non-SCST applicants up to the mean credit score in the sample (Figure 1 [based on the final Model 7], Model 5). However, after the mean value ( $\sim 40$ score), the odds of receiving a loan increase for SCST applicants. In other words, for a 10-point increase in credit score, those belonging to SCST had 1.02 times (1.05 for SCST minus 1.03 for non-SCST) higher 
odds of receiving a loan. ${ }^{1}$ To compare effects, we have provided OLS estimates in the Online Appendix, Table A1.

We further delve into the interaction plot in Figure 1. We specify a piece-wise regression with a subsample SCST vs. non-SCST and, within each subsample, we create two categories at or above the credit score of 641 or below the credit score of 641. In Figure A2, we present linear and non-linear fit plots above and below the mean cutoff. For the dashed line (SCST), the odds of funding are generally higher than those in the non-SCST category, except at low levels of credit scores. Although the estimates support Hypothesis 2, the nuanced observation is that the odds improve significantly for female micropreneurs from a lower caste when credit scores are better than the mean.

Hypothesis 2 on the added benefit of signals of business ability was not supported (Table 2, Model 6). Overall, $\mathrm{H} 1$ is supported, but $\mathrm{H} 2$ is not. Considering the findings together, when applicants from a lower caste are well below the mean credit score, candidates from a higher caste are preferred. However, for applicants from a lower caste with a credit score above the mean, the odds of receiving a loan are higher than for applicants from a higher caste. Overall, our findings indicate that improving the credit score above the mean delivers the most pronounced benefit for female micropreneurs from a lower caste.

\footnotetext{
${ }^{1}$ The effects are calculated as follows from Model 11, based on raw coefficients: slope for SCST $=0: \mathrm{b}$ [credit score $]=.0024$; odds ratio $=1.003$ slope for SCST $=1: \mathrm{b}[$ credit score $]+\mathrm{b}[\mathrm{SCST} \times$. credit score $]=.0024+.0030=.0054$; odds ratio $=1.005$ intercept for SCST=0: _cons $=-3.475$ intercept for SCST $=1$ : _cons $+b[S C S T]=-3.475-1.897=-5.372$
} 


\section{Robustness Checks}

When controlling for the branch fixed effects (Table A2, Model 1) or specifying probit and complementary log-log specifications (Table A2, Models 2 and 3) the effects are consistent with the main effects. We find no support for systematic discrimination in loan sanctioning between Hindu women and women from other religious minorities exists (Table A3).

In addition to the size of business premises as a signal of business ability, Table A4 presents the robustness of findings under additional signals of (i) log of annual income; (ii) customer-facing business; (iii) years self-employed; and (iv) household ownership (ancestral, leased, rented, or selfowned). In Table A4, consistent with inferences for $\mathrm{H} 2$, we find that these signals do not improve the odds of receiving a loan.

\section{Conclusion}

Discrimination against female entrepreneurs is well established (Carter et al., 2007). We find that, relative to females from higher castes, females from lower castes are less likely to receive loans until they surpass the mean credit score of 641. Providing visible signals of business ability (square footage of the business or additional signals) do not help to improve the odds of receiving a loan. The findings differ from Raj and Sasidharan (2018) who focused on the variations in access to formal credit for socially disadvantaged groups in India and found that socially disadvantaged firm owners had a lower probability of obtaining formal credit despite comparable creditworthiness. Their study focused on formal credit institutions, whereas our study focuses on microfinance, a distinct credit vehicle. More importantly, our findings do not categorically show that socially disadvantaged firm owners face systematic discrimination. As demonstrated in Figure 1, with increased creditworthiness, as represented by a credit score, the odds of receiving a loan increase 
for lower-caste females. Our theoretical context of microfinance is distinct from the formal credit receipts in the study by Raj and Sasidharan (2018) but, more importantly, our findings highlight the value of creditworthiness for socially disadvantaged female micropreneurs. We argue that the credit score as a demand-side signal is a viable approach to improve the odds of receiving a loan.

Related to the limitations of our study, as with several prior studies, we focus on loansanctioning outcomes without considering the subjective processes in loan decision making. The microloan organization in our sample has clear policies, uniform guidelines, and standardized loan-origination processes for loan applicants. The complex microdynamics related to homophily (for instance, loan officers from the same caste), role incongruity (for example, a Dalit woman opening an eatery vs. opening a sanitation business), and social bias provide some additional theoretical frameworks for further research. Focusing on intra-national variations future studies can also explore--do tribal women in tribal-dominated regions still, face discrimination? do migrants speaking the local language face discrimination in the regions they emigrate to? Considering matrilineal versus patrilineal institutions as further bases of discrimination would also be of interest. We call on future studies to assess the combination of remedial, reform, and revolution approaches (Sutter et al., 2019) from the perspective of how these levers can be applied to lower-caste-based discrimination. In conclusion, findings call for improved credit-scoring algorithms that compensate for disadvantages faced by lower-caste females, for enhanced training of loan officers, and for the development of more caste-blind microfinance loan policies. 


\section{References}

Agier, I., \& Szafarz, A. (2013). Microfinance and Gender: Is There a Glass Ceiling on Loan Size? World Development, 42, 165-181.

Aldrich, H., \& Auster, E. R. (1986). Even Dwarfs Started Small: Liabilities of Age and Size and Their Strategic Implications. Research in Organizational Behavior.

Bapuji, H., Ertug, G., \& Shaw, J. D. (2019). Organizations and Societal Economic Inequality: A Review and Way Forward. Academy of Management Annals(ja).

Bauchet, J., Chakravarty, S., \& Hunter, B. (2018). Separating the Wheat from the Chaff: Signaling in Microfinance Loans. World Development, 106, 40-50. doi:https://doi.org/10.1016/j.worlddev.2018.01.025

Baum, J. A., \& Shipilov, A. V. (2006). Ecological Approaches to Organizations.

Bumacov, V., Ashta, A., \& Singh, P. (2014). The Use of Credit Scoring in Microfinance Institutions and Their Outreach. Strategic Change, 23(7-8), 401-413.

Campbel, T. S., \& Kracaw, W. A. (1980). Information Production, Market Signalling, and the Theory of Financial Intermediation. The Journal of Finance, 35(4), 863-882.

Carter, S., Shaw, E., Lam, W., \& Wilson, F. (2007). Gender, Entrepreneurship, and Bank Lending: The Criteria and Processes Used by Bank Loan Officers in Assessing Applications. Entrepreneurship theory and practice, 31(3), 427-444. doi:10.1111/j.15406520.2007.00181.x

Cornée, S. (2017). The Relevance of Soft Information for Predicting Small Business Credit Default: Evidence from a Social Bank. Journal of Small Business Management.

De Vita, L., Mari, M., \& Poggesi, S. (2014). Women Entrepreneurs in and from Developing Countries: Evidences from the Literature. European Management Journal, 32(3), 451460.

Deshpande, A., \& Sharma, S. (2013). Entrepreneurship or Survival? Caste and Gender of Small Business in India. Economic and Political Weekly, 38-49.

Deshpande, A., \& Sharma, S. (2016). Disadvantage and Discrimination in Self-Employment: Caste Gaps in Earnings in Indian Small Businesses. Small Business Economics, 46(2), 325-346.

Goel, D., \& Deshpande, A. (2016). Identity, Perceptions and Institutions: Caste Differences in Earnings from Self-Employment in India.

Gutiérrez-Nieto, B., Serrano-Cinca, C., \& Camón-Cala, J. (2016). A Credit Score System for Socially Responsible Lending. Journal of business ethics, 133(4), 691-701.

Henry, C., Foss, L., \& Ahl, H. (2016). Gender and Entrepreneurship Research: A Review of Methodological Approaches. International Small Business Journal, 34(3), 217-241.

Iyer, L., Khanna, T., \& Varshney, A. (2013). Caste and Entrepreneurship in India. Economic and Political Weekly, 52-60.

Jodhka, S. S. (2010). Dalits in Business: Self-Employed Scheduled Castes in North-West India. Economic and Political Weekly, 41-48.

Jodhka, S. S. (2016). Ascriptive Hierarchies: Caste and Its Reproduction in Contemporary India. Current Sociology, 64(2), 228-243.

Justo, R., DeTienne, D. R., \& Sieger, P. (2015). Failure or Voluntary Exit? Reassessing the Female Underperformance Hypothesis. Journal of business venturing, 30(6), 775-792. 
Karlan, D. S., \& Zinman, J. (2008). Credit Elasticities in Less-Developed Economies: Implications for Microfinance. American Economic Review, 98(3), 1040-1068.

Kumar, S. M. (2013). Does Access to Formal Agricultural Credit Depend on Caste? World Development, 43, 315-328.

Microfinance Barometer. (2016). Convergences (Available From: Http://Www.Convergences.Org/En/).

National Research Council. (2004). Measuring Racial Discrimination: National Academies Press.

Parker, S. C. (2002). Do Banks Ration Credit to New Enterprises? And Should Governments Intervene? Scottish Journal of Political Economy, 49(2), 162-195.

Prakash, A. (2010). Dalit Entrepreneurs in Middle India. In B. Harriss-White \& J. Heyer (Eds.), The Comparative Political Economy of Development Africa and South Asia. London: Routledge.

Raj, S. R., \& Sasidharan, S. (2018). Does the Caste of the Firm Owner Play a Role in Access to Finance for Small Enterprises? Evidence from India. The Developing Economies, 56(4), 267-296.

Serrano-Cinca, C., Gutiérrez-Nieto, B., \& Reyes, N. M. (2016). A Social and Environmental Approach to Microfinance Credit Scoring. Journal of Cleaner Production, 112, 35043513.

Sidanius, J., \& Pratto, F. (2001). Social Dominance: An Intergroup Theory of Social Hierarchy and Oppression: Cambridge University Press.

Stiglitz, J. E. (1990). Peer Monitoring and Credit Markets. The world bank economic review, 4(3), 351-366.

Sutter, C., Bruton, G. D., \& Chen, J. (2019). Entrepreneurship as a Solution to Extreme Poverty: A Review and Future Research Directions. Journal of business venturing, 34(1), $197-$ 214.

Thorat, A. (2010). Ethnicity, Caste and Religion: Implications for Poverty Outcomes. Economic and Political Weekly, 47-53. 
Table 1. Sample Descriptives

\begin{tabular}{|c|c|c|c|c|c|c|c|c|c|c|c|}
\hline & variable & mean & $\mathrm{sd}$ & 1 & 2 & 3 & 4 & 5 & 6 & 7 & 8 \\
\hline 1 & Loan sanctioned & 0.44 & 0.50 & 1.000 & & & & & & & \\
\hline 2 & Microfinance credit score & 641.16 & 137.15 & 0.222 & 1.000 & & & & & & \\
\hline 3 & $\begin{array}{l}\text { SCST }=1 \text { (else }=0 \text { for General } \\
\text { and Other Backward Caste) }\end{array}$ & 2.06 & 1.19 & -0.020 & -0.015 & 1.000 & & & & & \\
\hline 4 & $\begin{array}{l}\text { Log of business premises size } \\
\text { (square feet) }\end{array}$ & 4.92 & 1.49 & 0.049 & -0.053 & 0.008 & 1.000 & & & & \\
\hline 5 & Loan amount & 97,320 & 18,120 & 0.025 & 0.008 & -0.006 & -0.012 & 1.000 & & & \\
\hline 6 & Age & 40.48 & 7.91 & 0.000 & 0.049 & 0.007 & 0.006 & 0.001 & 1.000 & & \\
\hline 7 & 12th pass (ref: 10th pass) & 0.05 & 0.23 & 0.008 & 0.004 & 0.014 & -0.012 & 0.004 & -0.094 & 1.000 & \\
\hline 8 & Graduate & 0.02 & 0.13 & -0.014 & -0.017 & -0.001 & -0.011 & -0.001 & -0.047 & -0.033 & 1.000 \\
\hline 9 & Illiterate & 0.19 & 0.39 & -0.027 & -0.033 & 0.007 & -0.004 & -0.032 & 0.183 & -0.116 & -0.066 \\
\hline 10 & Less than 10 th grade & 0.58 & 0.49 & 0.036 & 0.035 & -0.010 & -0.012 & 0.012 & -0.031 & -0.282 & -0.161 \\
\hline 11 & Postgraduate & 0.01 & 0.09 & 0.012 & 0.007 & -0.031 & -0.012 & -0.005 & -0.003 & -0.023 & -0.013 \\
\hline 12 & Separated (ref: married) & 0.01 & 0.07 & 0.009 & 0.014 & -0.015 & 0.033 & -0.017 & -0.011 & 0.042 & -0.010 \\
\hline 13 & Unmarried & 0.00 & 0.05 & 0.001 & -0.001 & 0.007 & 0.006 & -0.022 & 0.010 & 0.014 & -0.007 \\
\hline 14 & Widowed & 0.04 & 0.20 & -0.030 & 0.005 & -0.038 & 0.002 & -0.031 & 0.178 & -0.028 & -0.028 \\
\hline 15 & Hindu (ref: Christian) & 0.52 & 0.50 & -0.113 & -0.010 & 0.342 & 0.027 & -0.076 & 0.028 & -0.005 & -0.011 \\
\hline 16 & Muslim & 0.47 & 0.50 & 0.118 & -0.006 & -0.327 & -0.040 & 0.095 & -0.033 & 0.013 & 0.011 \\
\hline 17 & $\begin{array}{l}\text { Residential stability in the } \\
\text { present city }\end{array}$ & 26.01 & 12.17 & 0.002 & -0.001 & 0.005 & -0.023 & -0.025 & 0.373 & -0.016 & -0.025 \\
\hline 18 & Manufacturing (ref. others) & 0.06 & 0.24 & -0.001 & 0.020 & 0.001 & 0.109 & -0.055 & -0.049 & -0.038 & -0.015 \\
\hline 19 & Services & 0.41 & 0.49 & -0.057 & 0.010 & 0.021 & -0.095 & 0.008 & -0.049 & 0.032 & 0.017 \\
\hline 20 & Trading & 0.52 & 0.50 & 0.059 & -0.018 & -0.020 & 0.034 & 0.019 & 0.070 & -0.013 & -0.008 \\
\hline 21 & Family type & 0.77 & 0.42 & 0.049 & 0.003 & 0.055 & 0.048 & -0.021 & -0.051 & -0.021 & -0.032 \\
\hline
\end{tabular}

\begin{tabular}{|c|c|c|c|c|c|c|c|c|c|c|c|c|c|}
\hline & variable & 9 & 10 & 11 & 12 & 13 & 14 & 15 & 16 & 17 & 18 & 19 & 20 \\
\hline 9 & Illiterate & 1.000 & & & & & & & & & & & \\
\hline 10 & Less than 10 th grade & -0.574 & 1.000 & & & & & & & & & & \\
\hline 11 & Postgraduate & -0.046 & -0.112 & 1.000 & & & & & & & & & \\
\hline 12 & Separated (ref: married) & 0.011 & -0.021 & -0.007 & 1.000 & & & & & & & & \\
\hline 13 & Unmarried & -0.026 & -0.015 & -0.005 & -0.004 & 1.000 & & & & & & & \\
\hline 14 & Widowed & 0.065 & -0.006 & -0.019 & -0.015 & -0.011 & 1.000 & & & & & & \\
\hline 15 & Hindu (ref: Christian) & 0.072 & -0.054 & 0.024 & 0.025 & 0.004 & 0.008 & 1.000 & & & & & \\
\hline 16 & Muslim & -0.077 & 0.053 & -0.021 & -0.031 & -0.002 & -0.011 & -0.966 & 1.000 & & & & \\
\hline 17 & Residential stability in the present city & 0.134 & -0.045 & -0.031 & 0.017 & 0.036 & 0.141 & -0.018 & 0.011 & 1.000 & & & \\
\hline 18 & Manufacturing (ref. others) & 0.056 & -0.011 & -0.024 & 0.056 & -0.014 & 0.041 & 0.031 & -0.075 & -0.009 & 1.000 & & \\
\hline 19 & Services & -0.004 & -0.062 & 0.017 & -0.060 & 0.004 & -0.070 & 0.017 & -0.006 & -0.041 & -0.215 & 1.000 & \\
\hline 20 & Trading & -0.029 & 0.070 & -0.004 & 0.024 & 0.004 & 0.051 & -0.029 & 0.039 & 0.044 & -0.269 & -0.872 & 1.000 \\
\hline 21 & Family type $(0=$ Joint; $1=$ Nuclear $)$ & 0.019 & 0.017 & -0.004 & 0.039 & -0.055 & 0.037 & 0.098 & -0.110 & 0.012 & 0.114 & -0.142 & 0.086 \\
\hline
\end{tabular}

Note.

$N=3,144$

Correlations at or above $|0.035|$ are significant at $\mathrm{p}<0.05$ (two-tailed) or below. 
Table 2. Logit Estimates

\begin{tabular}{|c|c|c|c|c|c|c|c|}
\hline & \multicolumn{7}{|c|}{ Loan sanctioned $(0=$ no; $1=$ yes $)$} \\
\hline & $(1)$ & $(2)$ & (3) & $(4)$ & $(5)$ & $(6)$ & (7) \\
\hline \multirow[t]{2}{*}{ Microfinance credit score } & & $1.004 * * *$ & & $1.004 * * *$ & $1.003 * * *$ & $1.003 * * *$ & $1.003 * *$ \\
\hline & & $(0.000315)$ & & $(0.000315)$ & $(0.000336)$ & $(0.00117)$ & $(0.00123)$ \\
\hline \multirow[t]{2}{*}{ SCST } & & & 1.089 & 1.093 & $0.216 * *$ & & 0.0264 \\
\hline & & & $(0.116)$ & $(0.119)$ & $(0.141)$ & & $(0.0594)$ \\
\hline \multirow[t]{2}{*}{ Microfinance credit score $\times \mathrm{SC} / \mathrm{ST}$} & & & & & $1.002 * *$ & & $1.006 *$ \\
\hline & & & & & $(0.000967)$ & & $(0.00323)$ \\
\hline \multirow[t]{2}{*}{ Log of business premises size (square foot) } & & & & & & 0.993 & 0.962 \\
\hline & & & & & & $(0.153)$ & $(0.158)$ \\
\hline \multirow{3}{*}{$\begin{array}{l}\text { Microfinance credit score } \times \text { Log of business } \\
\text { premises size }\end{array}$} & & & & & & & \\
\hline & & & & & & 1.000 & 1.000 \\
\hline & & & & & & $(0.000225)$ & $(0.000240)$ \\
\hline \multirow[t]{2}{*}{ SCST $\times$ Log of business premises size } & & & & & & & 1.478 \\
\hline & & & & & & & $(0.596)$ \\
\hline \multirow{3}{*}{$\begin{array}{l}\text { Microfinance credit score } \times \text { SC/ST } \times \text { Log of } \\
\text { business premises size }\end{array}$} & & & & & & & \\
\hline & & & & & & & 0.999 \\
\hline & & & & & & & $(0.000578)$ \\
\hline \multirow[t]{2}{*}{ Loan amount } & 1.000 & 1.000 & 1.000 & 1.000 & 1.000 & 1.000 & 1.000 \\
\hline & $(2.16 \mathrm{e}-06)$ & $(2.09 \mathrm{e}-06)$ & $(2.15 \mathrm{e}-06)$ & $(2.10 \mathrm{e}-06)$ & $(2.09 \mathrm{e}-06)$ & $(2.08 \mathrm{e}-06)$ & $(2.07 \mathrm{e}-06)$ \\
\hline \multirow[t]{2}{*}{ Age } & 1.003 & 0.999 & 1.003 & 0.999 & 0.999 & 0.999 & 0.999 \\
\hline & $(0.00513)$ & $(0.00525)$ & $(0.00513)$ & $(0.00525)$ & $(0.00525)$ & $(0.00526)$ & $(0.00527)$ \\
\hline \multirow[t]{2}{*}{ 12th pass (ref: 10th pass) } & 1.206 & 1.190 & 1.199 & 1.188 & 1.182 & 1.212 & 1.206 \\
\hline & $(0.221)$ & $(0.223)$ & $(0.220)$ & $(0.223)$ & $(0.222)$ & $(0.228)$ & $(0.227)$ \\
\hline \multirow[t]{2}{*}{ Graduate } & 0.916 & 0.938 & 0.911 & 0.939 & 0.944 & 0.966 & 0.977 \\
\hline & $(0.267)$ & $(0.283)$ & $(0.266)$ & $(0.284)$ & $(0.285)$ & $(0.292)$ & $(0.296)$ \\
\hline \multirow[t]{2}{*}{ Illiterate } & 1.038 & 1.080 & 1.047 & 1.080 & 1.069 & 1.099 & 1.089 \\
\hline & $(0.135)$ & $(0.145)$ & $(0.137)$ & $(0.145)$ & $(0.144)$ & $(0.148)$ & $(0.147)$ \\
\hline \multirow[t]{2}{*}{ Less than 10th grade } & 1.166 & 1.149 & 1.160 & 1.149 & 1.144 & 1.164 & 1.162 \\
\hline & $(0.126)$ & $(0.127)$ & $(0.126)$ & $(0.127)$ & $(0.127)$ & $(0.129)$ & $(0.129)$ \\
\hline \multirow[t]{2}{*}{ Postgraduate } & 1.545 & 1.476 & 1.552 & 1.490 & 1.514 & 1.503 & 1.550 \\
\hline & $(0.610)$ & $(0.604)$ & $(0.614)$ & $(0.610)$ & $(0.622)$ & $(0.618)$ & $(0.642)$ \\
\hline \multirow[t]{2}{*}{ Separated (ref: married) } & 1.309 & 1.207 & 1.316 & 1.222 & 1.227 & 1.157 & 1.176 \\
\hline & $(0.665)$ & $(0.622)$ & $(0.669)$ & $(0.631)$ & $(0.632)$ & $(0.599)$ & $(0.608)$ \\
\hline Unmarried & 1.204 & 1.215 & 1.190 & 1.199 & 1.167 & 1.187 & 1.154 \\
\hline & $(0.817)$ & $(0.848)$ & $(0.808)$ & $(0.838)$ & $(0.814)$ & $(0.829)$ & $(0.805)$ \\
\hline Widowed & $0.683 * *$ & $0.667 * *$ & $0.700 *$ & $0.672 * *$ & $0.676^{* *}$ & $0.668 * *$ & $0.679 *$ \\
\hline & $(0.133)$ & $(0.133)$ & $(0.138)$ & $(0.134)$ & $(0.135)$ & $(0.133)$ & $(0.135)$ \\
\hline Hindu (ref: Christian) & 1.116 & 1.421 & 0.993 & 1.379 & 1.352 & 1.488 & 1.417 \\
\hline & $(0.324)$ & $(0.419)$ & $(0.303)$ & $(0.409)$ & $(0.401)$ & $(0.441)$ & $(0.423)$ \\
\hline Muslim & $1.834 * *$ & $2.377 * * *$ & $1.683^{*}$ & $2.383 * * *$ & $2.332 * * *$ & $2.512 * * *$ & $2.473 * * *$ \\
\hline & $(0.536)$ & $(0.705)$ & $(0.514)$ & $(0.707)$ & $(0.691)$ & $(0.749)$ & $(0.738)$ \\
\hline Residential stability in the present city & 1.000 & 1.001 & 1.000 & 1.001 & 1.001 & 1.001 & 1.001 \\
\hline & $(0.00326)$ & $(0.00335)$ & $(0.00326)$ & $(0.00335)$ & $(0.00335)$ & $(0.00336)$ & $(0.00337)$ \\
\hline Manufacturing (ref. others) & 1.966 & 1.886 & 1.974 & 1.903 & 1.970 & 1.987 & 2.070 \\
\hline & $(1.117)$ & $(1.093)$ & $(1.121)$ & $(1.104)$ & $(1.141)$ & $(1.155)$ & $(1.202)$ \\
\hline Services & 1.655 & 1.588 & 1.667 & 1.601 & 1.678 & 1.792 & 1.889 \\
\hline & $(0.912)$ & $(0.894)$ & $(0.918)$ & $(0.901)$ & $(0.943)$ & $(1.013)$ & $(1.066)$ \\
\hline Trading & 2.049 & 2.031 & 2.064 & 2.046 & 2.143 & 2.253 & 2.369 \\
\hline & $(1.128)$ & $(1.141)$ & $(1.135)$ & $(1.151)$ & $(1.202)$ & $(1.271)$ & $(1.334)$ \\
\hline Family type $(0=$ Joint; $1=$ Nuclear $)$ & $1.324 * * *$ & $1.334 * * *$ & $1.322 * * *$ & $1.331 * * *$ & $1.336 * * *$ & $1.329 * * *$ & $1.330 * * *$ \\
\hline & $(0.118)$ & $(0.122)$ & $(0.118)$ & $(0.122)$ & $(0.122)$ & $(0.122)$ & $(0.122)$ \\
\hline Constant & $0.162 * * *$ & $0.0131 * * *$ & $0.181 * *$ & $0.0131 * * *$ & $0.0160 * * *$ & $0.0111 * * *$ & $0.0158 * * *$ \\
\hline & $(0.112)$ & $(0.00961)$ & $(0.126)$ & $(0.00960)$ & $(0.0117)$ & $(0.0117)$ & $(0.0172)$ \\
\hline Observations & 3,144 & 3,144 & 3,131 & 3,144 & 3,144 & 3,144 & 3,144 \\
\hline Chi-2 & 75.16 & 245.4 & 73.92 & 246.1 & 253.1 & 259.4 & 268.6 \\
\hline $\mathrm{p}$ & $<0.001$ & $<0.001$ & $<0.001$ & $<0.001$ & $<0.001$ & $<0.001$ & $<0.001$ \\
\hline Pseudo R2 & 0.0175 & 0.0570 & 0.0172 & 0.0571 & 0.0588 & 0.0602 & 0.0624 \\
\hline
\end{tabular}

Notes.

Odds ratios reported

Standard errors in parentheses

$* * * \mathrm{p}<0.01, * * \mathrm{p}<0.05, * \mathrm{p}<0.1$

The estimates are consistent for models without controls and are available from the authors 


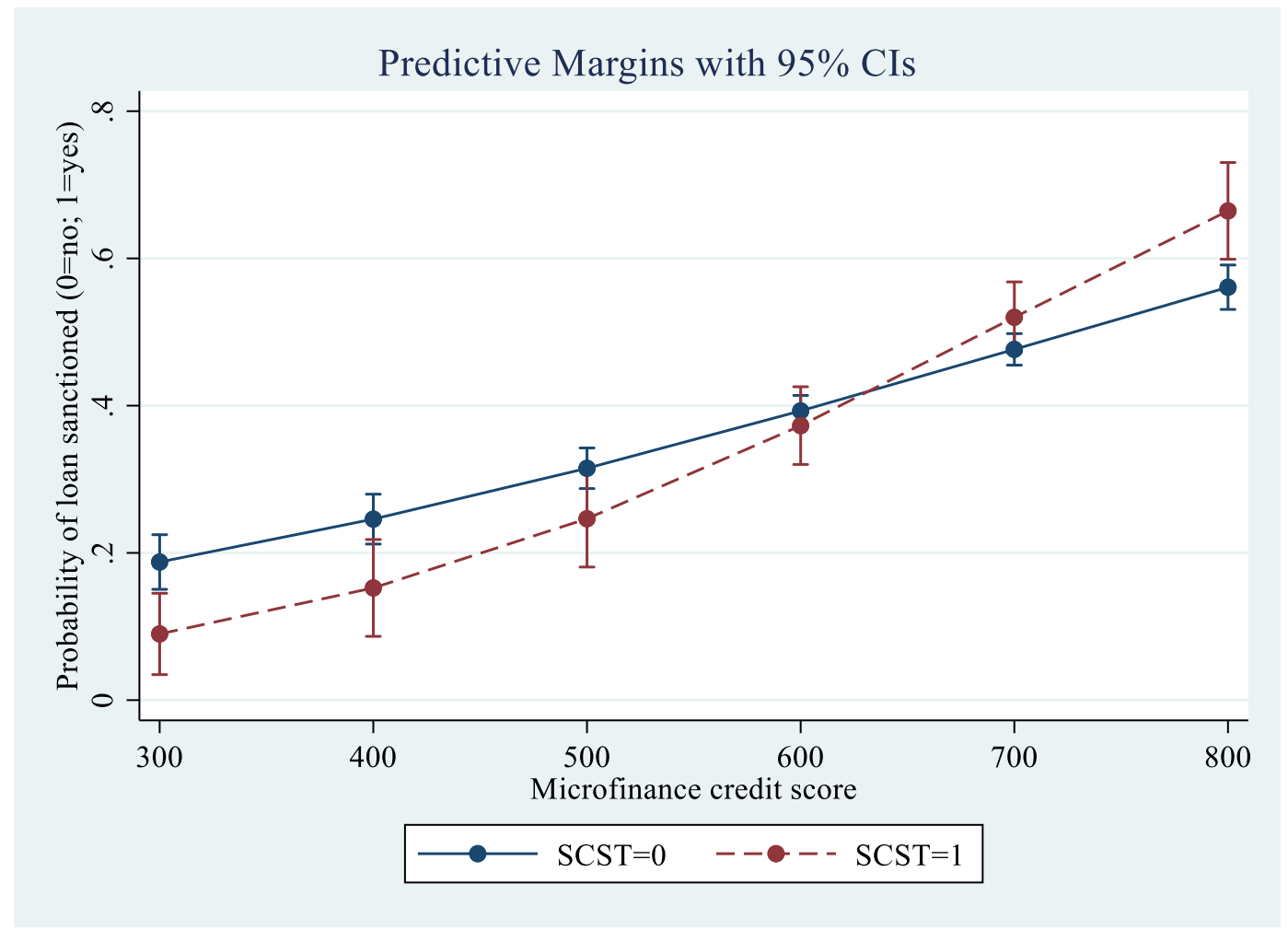

Fig 1. Moderation plot 